\title{
A Review: Extracellular Volume in the Brain - The Relevance of the Chloride Space
}

\author{
DONALD B. CHEEK ${ }^{(122)}$ AND A. BARRY HOLT
}

Royal Children's Hospital Research Foundation, Parkville, Victoria, Australia

By simultaneous infusion of anions into the blood and into the ventriculocisternal area it is possible to define two compartments, one of blood plus brain and one of cerebrospinal fluid (CSF) plus brain, with a zone of slow equilibration within the brain where the two components meet. It would appear that halogens $\left(\mathrm{Br}^{-}\right.$and $\left.\mathrm{I}^{-}\right)$have a much more remarkable and rapid entrance into brain tissue from blood and, with increasing blood concentration, penetrate the second compartment significantly. Chloride is more strongly transported across the choroid plexus from blood to CSF (in comparison with $\mathrm{I}^{-}$or $\mathrm{Br}^{-}$). Chloride should resemble $\mathrm{Br}^{-}$and $\mathrm{I}^{-}$in diffusing rapidly through the intercellular canals back into the blood. However, knowledge concerning $\mathrm{Cl}^{-}$distribution dynamics is meager.

The dynamics of chloride distribution, diffusion, and transport using, for example, ${ }^{36} \mathrm{Cl}^{-},{ }^{38} \mathrm{Cl}^{-}$, and stable $\mathrm{Cl}^{-}$, have not been studied sufficiently (in the two compartments), but circumstantial evidence would suggest that $\mathrm{Cl}^{-}$movement is more rapid in comparison to other ions across barriers. Ideally, when such studies are combined with the Van Harreveld freeze substitution technique, so that morphologic evidence can be compared with the volume of the chloride space in any region of the brain, the two measures should be in close agreement.

Probably chloride passes rapidly through canals (diameter 100-150 A) in the brain and such canals may, to some extent, be chloride or halogen perm selective (as in muscle tissue). The chloride concentration gradient within brain tissue (e.g., from cerebral cortex to ventricular wall) should be less than the concentration gradients of other ions (e.g., sulfate).

\section{INTRODUCTION}

The understanding of water and electrolyte distribution in the mammalian brain has been a subject of confusion and a matter for speculation and theory. However, significant advances have been made in recent years and a thorough review on the blood brain barrier is given by Rapoport (92). A diagnosis of "cerebral edema" (7) is frequently made during the course of disease in, for example, ketoacidosis (42), metal poisoning (3), or asphyxia $(10,14)$. However, we are without detailed understanding of the nature or mechanisms of brain edema. An increase of central venous pressure (venous hypertension) would appear to be involved in one type (32). Similarly, we do not understand derangement of ion transport. Why is there a sudden change in the blood-brain barrier during meningitis? (See Ref. 22 for review.) Why, for example, is the penetration of halogen into the CSF so rapid and characteristic of tuberculous meningitis early in the disease $(19,27)$ ?

The extracellular fluid (ECF) of the brain is of central importance to the supply of nutrients for growth for the circulation of hormones (see Ref. 41 for review) and for the dispersion of end products of metabolism. At the same time, CSF can contain excessive levels of some metabolites (e.g., bilirubin), which have deleterious effects in the neonate.

The purpose of the present paper is to review the literature concerning brain water and the chloride space ( $\mathrm{Cl}$ space) as a measure of extracellular volume (ECV).

The rhesus monkey (Macaca mulatta) is a useful experimental model. Comparisons of the macaque brain with the human brain during growth can prove rewarding. Our work on the growth of the macaque brain and the distribution of $\mathrm{Cl}^{-}$and $\mathrm{H}_{2} \mathrm{O}$ extends from midgestation ( 80 days) to term (165 days) and well into the postnatal period (120 days after birth). The results of this work have been documented in a recent publication (21).

\section{CSF CIRCULATION AND ITS BARRIERS}

Homeostasis and the constancy of Claude Bernard's "Milieu Interne" is essential for normal function of the central nervous system (CNS). Davson (33) has described the concepts of the blood-brain barrier and the circulation of the CSF. The brain and spinal cord are surrounded by the CSF. In the interior of the brain the ventricular systems exist, containing the CSF, which connects to the external fluid by a hole in the roof of the fourth ventricle (foramen of Magendie) or by holes in the lateral recesses of the same ventricle (foramina of Luschka) opening into the subarachnoid spaces at the base of the brain. No part of the CNS in the human is more than $2 \mathrm{~cm}$ distant from CSF (34). A main source of CSF (70\%) (92) is the choroid plexus within the ventricles; the reabsorption of fluid takes place to a large extent via the arachnoid villi which establish connection with the venous sinuses and dural sinuses. Those connections are valvular so that the flow is one way (115). The pressure of the CSF is greater than the venous pressure. The turnover of spinal fluid or rate of production and absorption decreases with increasing brain size for any species.

The early work of Goldmann (53) concerning the distribution of trypan blue in the nervous system can be interpreted as showing a double compartment system. Trypan blue, when injected into the blood, is not found in the nervous system. However, when the dye is infused into the CSF, it is found only in the brain.

In a recent review, Bering (8) considered the CSF in relation to the ECF of the brain. He pointed out that the CSF circulation from the cerebral ventricles through the subarachnoid space is unique to mammals and that the subarachnoid space parallels the development of the neocortex and intellectual function. Not only does the CSF provide mechanical protection for the brain, but it bathes the cortex with a physiologically beneficial environment while serving as a sink for brain metabolites. Although much remains to be known about the function of the CSF, certain important information is available. From a historic viewpoint, the CSF circulation was thought to originate by secretion of fluid from the choroid plexuses flowing at a steady rate out of the ventricles to the subarachnoid space, where it was drained into the sagittal sinus. We now know that this is only partly correct. It is true that the CSF comes from the choroid plexuses but also it is produced by the ventricular walls of the brain and also by the subarachnoid pial surface (85). In- 
deed, CSF is still formed when the choroid plexus is removed in the rhesus monkey (74-76).

The CSF circulates in a pulsatile fashion in line with the arterial blood pressure. There is a net movement of fluid out of the ventricular system, while the intraventricular CSF formation equals the rate at which fluid is lost. As the intracranial volume increases with each arterial pulse there is a momentary increase of the contents of the intracranial cavity and the contents of the ventricular system with swelling of the choroid plexus. The increase in the volume of the brain is offset by the CSF flowing down over the cerebral surface, out of the cranium, and into the spinal subarachnoid space as the brain fills with blood. Also, CSF moves out of the ventricles, filling the subarachnoid space at the end of the systole. The blood continues to drain away from the brain and the choroid plexus, decreasing the intracranial contents while the CSF flow reverses and fluid returns to the subarachnoid space over the cortex and into the ventricles. There is a net loss of fluid with each systole which, in the course of time, is equal to the rate of CSF formation.

For most major electrolytes there is a strong similarity between the composition of CSF and the ECF of brain tissue (28). Blood plasma composition is also similar except for modifications imposed by the much lower protein content in CSF and a higher $\mathrm{Cl}$ concentration (higher than would be predicted on the basis of a simple Gibbs-Donnan equilibrium with blood).

The CSF composition reflects the metabolic action of the brain and the choroid plexus. The end result is a fluid with special composition, propitious for the conduction of nervous impulses. This fluid has low concentration of $\mathrm{K}^{+}$and $\mathrm{Ca}^{++}$and elevated $\mathrm{Na}^{+}$and $\mathrm{Mg}^{++}$levels which reflects the differences between the CSF and blood within the brain (the blood-brain barrier) and also the blood-CSF barrier (at the choroid plexus). Peripheral nerves also have a barrier at the blood vessels of the endoneurium and at the perineurium which surrounds the nerve bundles.

All barrier sites are characterized by cells connected by "tight junctions" (Fig. 1) that restrict intercellular diffusion. Such cells are endothelia of blood vessels, epithelia of the choroid plexus, or cells of the arachnoid and perineurium. Such cells are closely connected, acting as a continuous layer with solute exchange occurring by the transcellular route. Therefore, cells and their membranes at barrier sites are responsible for the permeability and transport of solute and for regulating such transport (92).

The CSF is in communication with the ECF between the brain cells which, in this review, we shall refer to as the intercellular space of brain tissue. In that location the composition of the

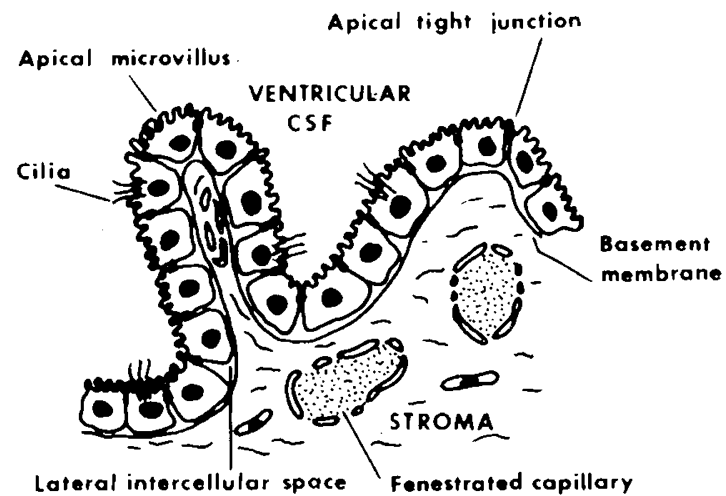

Fig. 1. Features of a choroid plexus villus. The villus is covered by a single layer of cuboidal epithelium with apical microvilli facing on ventricular CSF and the basal cell surface placed on a basement membrane. Tight junctions connect the apical regions of the cell membranes. The lateral intercellular spaces swell and shrink (due to choroid secretion). The villus separates choroidal stroma from CSF. Capillaries within the stroma have a fenestrated endothelium. (Reprinted by permission of Dr. S. I. Rapoport (92), Blood-Brain Barrier in Physiology and Medicine (1976), and by Raven Press, New York.) fluid is probably very similar to that in the spinal fluid. It is recognized that the composition of CSF varies slightly from point to point and wherever a sample may be taken, reflecting the interaction between the extracellular space of the brain and the CSF.

\section{PASSAGE OF SOLUTE AND CHOROID PLEXUS}

Active transport mechanisms located in the choroid plexus "pump" substances from CSF to blood. This has been shown for iodide $(1,9)$, thiocyanate $(83), p$-aminohippurate $(36)$, and sulfate $(30,31)$ and bromide (9). Indeed, the cells of the choroid plexus have the same characteristics as those of the renal tubule $(8,17)$, so that one could regard the plexus as a "neural kidney." Other markers such as inulin, unlike halogen, have little or no passage back from CSF to blood or from CSF into the intercellular space of brain (98). In the latter instance the concentration of inulin decreases as a function of the distance from the ventricular surface in a manner consistent with diffusion as shown by Rall et al. (90). Chloride in particular has a most active transport from blood to $\operatorname{CSF}(8,28)$.

Although the passage of certain solutes from blood to CSF or blood into brain tissue is limited, the passage of solute from ventricular fluid through the ependymal lining to the intercellular fluid is rapid for certain solutes (e.g., iodide), but retarded for larger molecules (e.g., inulin, sucrose). Similarly, the passage of small ions is again easier from CSF to blood at the choroid plexus. The choroid plexus then is not the only pathway from blood to brain or brain to blood. Passive solute exchange at the choroid plexus is restricted by tight junction between choroidal epithelia. The choroid plexus is a villous structure extending from the brain surface "like coral fronds into a sea of CSF" (92).

The CSF results from active transport of $\mathrm{Na}^{+}$across the choroid plexus into the CSF (with the passive diffusion of water). Active processes also operate to transport substances back via the choroid plexus into the blood stream (see Ref. 28 for review). One can elevate or lower plasma $\mathrm{K}^{+}$without altering CSF $\mathrm{K}^{+}$concentration. The turnover of CSF is vital and continuous and of fundamental importance with respect to the nutrition of brain cells, transport of glucose and amino acids, and removal of expended metabolites, thus serving a similar function to the lymphatic system in the soma. Erythrocytes appear to be involved in amino acid transport into the CSF (41, 56), whereas $\mathrm{Na}^{+}$transport is important to the entrance of amino acids into cells (97).

\section{IS ECV OF BRAIN A ONE- OR TWO-COMPARTMENT} SYSTEM?

One can argue that the plasma and interstitial space and part of the intercellular space is one component of the extracellular phase whereas the distal part of the canals within the brain close to and together with the CSF is a second component of the ECF. Milhorat studied brain slices in the rhesus monkey after the injection of ${ }^{24} \mathrm{Na}$ into the circulation (75). The concentration of ${ }^{24} \mathrm{Na}$ was observed from the ventricles and surrounding gray matter through the white matter and out to the brain cortex (gray matter). The concentration of ${ }^{24} \mathrm{Na}$ decreased from the ventricle through the white matter to one-quarter of the original concentration, but increased again to almost the starting level when the cortex was reached.

Unfortunately, in early work, it was thought that injection of solute into the vascular supply to the brain would define a close measure of true ECF volume. By such means values of $1-4 \%$ of brain volume were obtained $(2,5,16,35,37,45,46,49,60$, $66,68,78,90-94,101,104,110,117,121)$. Astrocytes and membrane remain close to capillary endings, providing a barrier to solute passage, hence explaining this phenomenon.

It was perhaps equally unfortunate that early studies of the histology of brain by electron microscopy also revealed falsely low estimates of ECV (morphologic aspects will be discussed 
under Section VIII). Other studies concerning perfusion of solute into the ventriculocisternal area $(4,29,118,119)$ took account of the outward transport of solute from CSF to blood. However, for accurate appraisal of "solute space," one requirement is that the concentrations must be equal in plasma and ventriculocisternal perfusate simultaneously $(1,3,9,31,67,83$, $87,91)$. Even under these conditions, one cannot assume that such a solute space is equivalent to "extracellular space," especially if the concentrations on either side of the blood-brain barrier and blood CSF barrier are insufficient to prevent escape of ions into the systemic circulation. Moreover, the concentration of an ion may be the same in plasma water and CSF but the concentration in the intercellular canals may fluctuate either because of escape into the systemic circulation or because of diffusion and molecular size.

The concept of a two-compartment system with blood on one side and CSF on the other with the extracellular space within brain tissue as the location of exchange is supported by the work of several investigators. For example, as shown by Oldendorf and Davson (82), if a solute (such as sucrose) is injected into the ventriculocisternal area of the rabbit (in mock CSF) the apparent space (intercellular) may reach $6-8 \%$ of brain tissue at a time when the level of sucrose is almost zero in blood plasma, again illustrating the inability of saccharides to cross from the intercellular space to the vascular system. If sucrose is given by the systemic blood circulation and a constant level is reached in the blood, the sucrose space is even smaller and if sucrose or some other solute finds its way from blood into the intercellular space of CSF, it is rapidly removed by the CSF turnover. However, this "sink action" from blood to CSF may not be very remarkable.

If sucrose is given by both routes simultaneously and at equal concentrations, then one can define the intercellular space and also the space related to plasma perfusion, yielding a total "sucrose space." This in turn may represent an approximation of the true or total extracellular space (82). Not only is the concentration of the infusate important but transport mechanisms must be saturated so as to allow maximal diffusion of ions.

\section{HOW DOES ECV OF SOMA COMPARE WITH THAT OF BRAIN?}

\section{CONSIDERATION OF HALOGEN}

In 1937 Hastings and Eichelberger (54) had already considered ECF to be a simple ultrafiltrate of serum, but Manery et al. (70) soon drew attention to a higher concentration of chloride in connective tissue; they believed that the extracellular phase of the soma was really a connective tissue phase diluted by an ultrafiltrate of plasma. Brain contains no collagen (other than in vessels and membranes covering the brain) and, therefore, the original definition by Hastings could be applicable to brain.

Manery and Hastings in 1939 (72) analyzed many tissues in the rat and rabbit and, on the basis of previous work, regarded $\mathrm{Cl}^{-}$as the extracellular ion and $\mathrm{K}^{+}$as the marker for the intracellular phase. An inverse relationship was obtained when the $\mathrm{Cl}^{-}$(in milliequivalents per $\mathrm{kg}$ of total tissue water) was plotted against the $\mathrm{K}^{+}$(in milliequivalents per $\mathrm{kg}$ of total tissue water). Data points for brain tissue fell exactly on this line. Tissues high in $\mathrm{K}$ content contained a low $\mathrm{Cl}$ concentration and vice versa.

The above facts, together with the work of earlier investigators are now of historic interest. Their work and subsequent investigation, reviewed in detail by Cheek (20), has established the concept that the distribution of chloride is a reliable measure of extracellular volume in most tissues. In later years, work by Cheek and West (23) and Cheek et al. (24) assessed the distribution of $\mathrm{Cl}^{-}$and $\mathrm{Na}^{+}$in different tissues of the rat in separate experiments, and demonstrated that $12 \%$ and, at the most, $15 \%$ of $\mathrm{Cl}^{-}$was intracellular in the soma. Edelmann and Leibman (43) subsequently considered the value of $12 \%$ for the human adult. Cheek et al. (24) found in the rat that some $30 \%$ of $\mathrm{Na}$ was outside the ECF. The correction of the $\mathrm{Na}^{+}$space for nonextracellular $\mathrm{Na}^{+}$and the $\mathrm{Cl}^{-}$space for intracellular $\mathrm{Cl}^{-}$in separate experiments yielded ECVs that were almost identical. At the same time it was realized that $\mathrm{Cl}^{-}$within the cells was located in red blood cells and in other tissues (gastric epithelium, renal tubules). Even the most recent attempts to ascribe significant amounts of $\mathrm{Cl}^{-}$to the intracellular phase of muscle (6) failed to recognize the penetration of $\mathrm{Cl}^{-}$into the longitudinal and transverse canals of muscle-canals continuous with the extracellular phase $(44,61)$ and selectively permeable to chloride, but not to nitrate $(52,99)$, and, therefore, not to sulfate.

These intercellular canals present as organelles in muscle fiber are located mainly above and below the " $Z$ line." Huxley (61) and Endo (44) identified by special techniques the existence of these transverse and longitudinal canals or tubules ( $T$ tubules) in the frog sartorius muscle or in the frog twitch fiber of $100-$ $150 \AA$ in diameter and demonstrated continuity with the ECF of muscle. Where the terminal regions of the longitudinal system of the reticulum come into contact with the transverse system, a characteristic structure called a triad is formed. This triad is in continuity through pores in the plasma membrane with the ECF. Huxley used ferritin molecules (with diameter of $100 \AA$ ) to demonstrate this special extracellular system within the cellular phase. Endo used fluorescent dye (44). The question does arise of whether other canals within other tissues (such as brain) could be anion perm-selective and even halogen-specific, especially as canals of 100-150 ̊ exist in the brain, as will be discussed later.

It is important also to point out that before our work on tissue chloride analysis in 1954 (23) and the later work of Cotlove (26) chemical measurements of chloride in tissues were imprecise because of the presence in tissues of $-\mathrm{SH}$ groups which combine with silver during titration. The method we established using microdiffusion (23) excluded the- $\mathrm{SH}$ groups, whereas the method of Cotlove (26) destroyed these groups by the addition of perborate during analysis. Before 1954 there was, we found, a large variation in the determination of muscle chloride content (for example) in rats of comparable age. Our own method and the subsequent method of Cotlove gave identical answers. Thus it is important to inspect all papers with a critical eye as to the method used for tissue chloride determination.

The need to consider-SH groups was illustrated by the chloride analyses of Bourke et al. (12). They found that samples of cerebral cortex gave values that were $25 \%$ above the actual value when the tissues were not subjected to either alkaline digestion or to perborate oxidation.

Bromide distributes similarly to chloride in almost all organs resembling an isotope of chloride; hence this ion is of interest $(15,23,50,51,55,111,112,114)$. In almost all organs $\mathrm{Br}^{-}$ and $\mathrm{Cl}^{-}$distribute commensurately and the ratio of $\mathrm{Cl}^{-}$content to $\mathrm{Br}^{-}$content is reflected in the ratio of serum $\mathrm{Cl}^{-}$to serum $\mathrm{Br}^{-}$. The early studies of Weir (113) and Wallace and Brodie $(111,112)$ indicated that bromide can be transported slowly from blood to CSF or vice versa. The ratio of brain content to CSF concentration of $\mathrm{Br}^{-}$, is similar, however, to the chloride content relative to the serum $\mathrm{Cl}^{-}$concentration. In the brain a much smaller amount of $\mathrm{Br}^{-}$penetrates the tissue, provided the blood-brain barrier is intact.

Weir $(113,114)$ investigated the permeability of the blood brain barrier to $\mathrm{Br}^{-}$in dogs using moderate to very high dose levels of $\mathrm{NaBr}$. Serum ultrafiltrate concentrations varied as much as $1-90 \mathrm{mM} / \mathrm{kg} \mathrm{H} \mathrm{H}_{2} \mathrm{O}$. In the human with levels of serum $\mathrm{Br}^{-}$at $1-2 \mathrm{mEq} /$ liter the ratio of $\left[\mathrm{Br}^{-}\right]_{s}:\left[\mathrm{Br}^{-}\right]_{\mathrm{CSF}}$ is 3.0 under normal circumstances. In the dog, however, the ratio is lower, being about 1.7-1.9. With serum $\mathrm{Br}^{-}$levels of $22 \mathrm{mEq} /$ liter of water in the dog the ratio falls to 1.2 , whereas very high serum levels of $70 \mathrm{mEq} /$ liter yield ratios of 1.04-1.07, indicating that the permeability of $\mathrm{Br}^{-}$through the blood brain barrier increases with increasing serum concentration so that it approximates $\mathrm{Cl}^{-}$ penetration. The same behavior is found with iodide. Why the dog possesses this higher ratio at small concentrations is not 
clear, but the increased ability for $\mathrm{Br}^{-}$or $\mathrm{I}^{-}$to enter the CNS with increasing plasma concentration underscores the ability of halogen to rapidly encompass a definite compartment of the brain. Possibly, at high concentrations $\mathrm{Br}^{-}$distributes similarly to $\mathrm{Cl}^{-}$(as with other tissues). Weir's paper (113) has not received the attention it deserves. Thus consideration of the distribution of $\mathrm{Cl}^{-}, \mathrm{Br}^{-}$, or $\mathrm{I}^{-}$as a measure of $\mathrm{ECV}$ in the brain requires careful study.

\section{CONSIDERATION OF POLYSACCHARIDES AND OTHER SOLUTES}

Over the years many investigators have used polysaccharides to define ECV (see Ref. 24 for review). As stated by Bourke et al. (12), "most investigators would accept the premises that the inulin molecule (or sucrose) is metabolically inert, is not subject to carrier mediated transport and is unable to penetrate into cells, i.e. it is restricted to the extracellular fluid."

The concept of slow and fast movement of solute markers into the extracellular phase has been recognized for somatic tissues. Nichols et al. (81) showed that inulin, sucrose, and sulfate rapidly diffuse across the plasma and interstitial water but only slowly penetrate connective tissue water (skin and tendon) and never completely equilibrate with the chloride space of these tissues. Although collagen is not present in brain tissue, it is known that mucopolysaccharides or polyanions exist in the intercellular canals of the brain (89). Hence a similar situation could exist in brain. White and Rolf (116) showed that macrophages ingested inulin such that one had to estimate total tissue inulin to measure the true volume of distribution. For muscle, one has to perfuse the tissue for many hours before the inulin or sucrose spaces equal the $\mathrm{Cl}^{-}$space $(25)$.

Studies concerning the distribution of polysaccharides in the CNS led Katzmann et al. (65) to conclude that sucrose entered neurones. Brown et al. (16) found that $10-15 \%$ of inulin penetrated sympathetic ganglia in cats after parenteral infusion. Nicholls and Wolfe (80), using autoradiography, showed that dextran, inulin, and sucrose enter both neurones and glial cells. They obtained evidence that an energy-required system was needed for this intracellular distribution. Shaywitz and Escriva (98) suggested that pinocytosis is the most likely mechanism. On the other hand, Nicholls and Kuffler (79) studied glial cells in the leech and frog and found them to be high in $\mathrm{K}^{+}$ concentration and to contain no $\mathrm{Cl}^{-}$; thus, such cells do not contribute to the extracellular phase in such species.

In 1956 White and Rolf (116) investigated the distribution of inulin in nephrectomized rats over periods ranging from $0.5 \mathrm{hr}$ up to $72 \mathrm{hr}$. It was found that inulin was slowly destroyed in the body and that under the conditions of the experiment inulin entered cells such that the inulin space at $72 \mathrm{hr}$ was greater than total body water! In contemporary work, Cheek et al. (24) obtained evidence that inulin entered liver cells. White and Rolf (116) also noted that the chloride space increased with time in nephrectomized rats whereas the sodium space remained the same, indicating entrance of $\mathrm{Cl}^{-}$into cells after nephrectomy. Similar conclusions were drawn by Finkenstaedt et al. (48), who found in nephrectomized dogs that the inulin space continued to rise for $150 \mathrm{hr}$, approaching total body water. Under conditions of nephrectomy, an alteration in distribution of electrolyte may occur with the penetration of inulin of $\mathrm{Cl}^{-}$into the cellular phase. For example, the bromide space of dogs increases when the renal circulation is suddenly obstructed (unpublished observation, D. B. Cheek and C. D. West). Moreover, under experimental conditions where there is retention of excess water, glial cells have a reduction in activity of $\left(\mathrm{Na}^{+}-\mathrm{K}^{+}\right)$ ATPase (73) associated with abnormal electrolyte equilibrium a situation which could pertain after nephrectomy. Thus, it seems clear that polysaccharides can penetrate cells in somatic and neural tissues and that under conditions of nephrectomy the $\mathrm{Cl}^{-}$space may also be unreliable as a marker in somatic tissues. Except for muscle, the $\mathrm{SO}_{4}$ ion distributes similarly to $\mathrm{Cl}^{-}$in somatic tissues and in the CNS (Section $V$ ), whereas $\mathrm{SCN}^{-}$also distributes similarly, although some binding to protein is known to occur (see Ref. 20 for review).

\section{HOW DOES HALOGEN COMPARE WITH OTHER MARKERS IN DEFINING ECV OF BRAIN?}

Bourke et al. (12) in 1965 studied the distribution of labeled sucrose, inulin, and thiocyanate in the cerebral cortex of the guinea pig, rabbit, cat, monkey ( $M$. mulatta), sheep, and chimpanzee while the endogenous $\mathrm{Cl}^{-}$space was measured in all these mammals or data were taken from the literature. Data were provided also concerning the mouse, rat, ox, and man. During intracisternal perfusion it was found that labeled sucrose or inulin did not distribute evenly throughout the CSF. The concentrations depended on the site of CSF sampling. The relatively slow efflux of sucrose or inulin from CSF did-not apply to thiocyanate. Rapid disappearance of thiocyanate occurred from the cisternal CSF and the levels reached elsewhere never reached equilibrium with those in the cisternal fluid. Sequestration of cisternally injected sucrose and inulin was demonstrated in the lumbar CSF of cat and macaque. This sequestration did not occur for $\mathrm{SCN}^{-}$or for $\mathrm{Cl}^{-}$where the concentration was uniform throughout the fluid volume perfused.

Bourke et al. (12) found that the efflux of sucrose and inulin was very slow out of the CSF and the rate was half of that for $\mathrm{Na}^{+}$, whereas the rates for $\mathrm{SCN}^{-}$and $\mathrm{I}^{-}$were 2.5 times that of sodium or 3 times that of sucrose. There was no evidence of a transport mechanism out of the CSF for either sucrose or inulin. In contrast, there was an active transport process for, $\mathrm{Cl}^{-}, \mathrm{Br}^{-}$, $\mathrm{SCN}^{-}$, and sulfate from CSF to blood. The site for such transport appears to be primarily the choroid plexus.

Bourke et al. (12) considered that the greater space for chloride or $\mathrm{SCN}^{-}$(which gave equal values) than for sucrose and inulin (which also defined similar volumes) in the cerebral cortex was related to tissue binding or an intracellular location for $20 \%$ of $\mathrm{Cl}^{-}$in the mouse, rat, guinea pig, rabbit, cat, monkey, sheep, ox, chimpanzee, and man. This is an assumption. As stated, there was a constant percentage difference between the chloride or $\mathrm{SCN}^{-}$space and the inulin or sucrose space. These workers were persuaded that these differences supported the existence of intracellular $\mathrm{Cl}^{-}$.

The chloride or $\mathrm{SCN}^{-}$space in the mature brain appeared to increase with mammalian size. The chloride or $\mathrm{SCN}^{-}$space for the mouse was $17.0 \%$, for the monkey $49.1 \%$, and for man $60.4 \%$. For the inulin or sucrose space the value for the mouse was $8.5 \%, 32.8 \%$ for the monkey, and $45.2 \%$ for man.

The suggestion that halogens may move in a specific way and rapidly through the ECV intercellular spaces of the brain was supported by the observations of Reed and Woodbury (93). After cisternal injection of isotopically labeled iodide, sucrose, inulin, and albumin into the nephrectomized rat they found that the iodide space curve differed markedly from the curves for the three other substances. The iodide space was much larger and the movement of $\mathrm{I}^{-}$much faster than that for the other tracers. The space occupied by the other agents after $2 \mathrm{hr}$ was the same. The investigators commented that "there are pathways available for the exit of iodide from CSF which are not available to other tracers." At the same time, they noted that when the tracers were given iv to nephrectomized rats, the rate of entrance into the brain was inversely related to the molecular weight of the tracer substance.

Levin et al. (67), in an important study, infused radiolabeled sulfate and labeled inulin either simultaneously or separately into the subarachnoid space and into the vascular circulation of rabbits. Blood and CSF samples, as well as successive layers of brain tissue (parallel to the plane of infusion), were analyzed. They found that they did have a two-compartment system, both compartments of which gradually "filled up" as time progressed. There was no back diffusion of sulfate into the CSF (i.e., no "sink" action), nor was the sulfate excreted by the choroid plexus. They suggested that methods applying extrapolation of 
concentration data to the tissue fluid interface, as used by previous workers $(30,66,68,87,88)$, gave values more appropriate to the real size of the cerebral extracellular space. For the vascular side, the sulfate space was $5 \%$, whereas on the CSF side the value was $16 \%$ by volume, making a total of $21 \%$. Analyses of successive layers of brain material showed a decreasing $\mathrm{SO}_{4}=$ concentration as the slices were sampled deeper in the brain (concentrations in the intercellular spaces).

The observation by Levin et al . (67) is of considerable importance. After ventriculocisternal perfusion to yield a constant concentration of $\mathrm{SO}_{4}{ }^{=}$within the brain tissue, the irrigation of the brain with "mock" CSF rapidly reduced the $\mathrm{SO}_{4}=$ concentration within the brain slices. In contrast, after blood perfusion with $\mathrm{SO}_{4}=$ irrigation of the arachnoid space with "mock" CSF, no entrance of $\mathrm{SO}_{4}=$ into $\mathrm{CSF}$ was revealed (no sink action). It would appear, that, at least for $\mathrm{SO}_{4}=$, no sink action from blood to $\mathrm{CSF}$ exists. Since $\mathrm{Cl}^{-}$distributes similarly to $\mathrm{SO}_{4}{ }^{2}$, one wonders whether a sink action exists for that ion. No such definitive experiments have been done.

For inulin in the rabbit's brain the total space was $16 \%(67)$ The difference between the inulin space and the sulfate space was due to the different penetration of $\mathrm{SO}_{4}=$ and inulin into the blood-brain barrier, not the intercellular CSF space (both agents gave a value of $14 \%$ for the CSF and the intercellular space of brain). Levin et al. (67) reviewed data obtained in cats, rats, and rabbits when the brain was perfused by the ventriculocisternal route and by the vascular system simultaneously. The values for iodide for the rabbit brain varied from 19 to $22 \%(1,9)$. For sucrose in the rabbit brain the perivascular space equaled $2.7 \%$, in the CSF $6 \%$, with a total space of $9 \%$. For thiocyanate the perivascular space was $5-7 \%$ whereas the CSF space was $20 \%$ with a total space of $26 \%$. For inulin the perivascular space was $1.7-2.3 \%$, for CSF $14 \%$, and the total space equaled $16.5(67)$.

A two-compartment system joined by a slowly equilibrating zone would appear to exist within the extracellular space of brain tissue. The blood on one side and CSF on the other are the mainstreams while the brain is the area of slow equilibration. Such a notion was supported by the ${ }^{24} \mathrm{Na}$ studies of Milhorat (75) described in Section III.
From the above experiments it would appear that the halogen spaces and the sulfate space are similar as in most somatic tissues. The evidence would suggest that polysaccharides do not penetrate the perivascular space and therefore do not account for the entire ECV of the nervous system.

\section{WHAT IS KNOWN CONCERNING LIMITS OF HALOGEN SPACE IN CNS?}

In 1962 Vernadakis and Woodbury studied the changes in endogeneous brain electrolyte and water for normal rats aged 1 to 45 days. The cerebral cortex was studied (112). The water content progressively decreased from $88 \%$ to $79 \%$ over the age period studied. The chloride space decreased during maturation from $47 \%$ at 1 day to $35 \%$ at 12 days, $25 \%$ at 17 days, and $24 \%$ at 21 days, after which stability was reached. By contrast, the nonchloride space (total water-chloride space) rose in these periods from $40 \%$ to $48 \%$ (12 days), to $55 \%$ at 17 days, and then reached stability. The sodium space followed the $\mathrm{Cl}^{-}$space until 10 days then showed a slight but constant increase over the chloride space. This was a very important study as it defined for the first time the $\mathrm{Cl}^{-}$space in the cerebral cortex of the brain of the rat, a well studied laboratory animal. In Figure 2 the $\mathrm{Cl}^{-}$ space and total water minus the $\mathrm{Cl}^{-}$space is shown for the cerebrum and cerebellum of the fetal macaque from midgestation to 120 days postnatally. Figures 3 and 4 illustrate the distribution of $\mathrm{Na}^{+}$relative to $\mathrm{Cl}^{-}$in the cerebrum and cerebellum during development whereas Figures 5 and 6 demonstrate the relationship between water and the major components of brain composition during growth.

Vernadakis and Woodbury (110) subsequently studied the distribution of ${ }^{36} \mathrm{Cl}^{-}$in the cerebral cortex of nephrectomized rats and suggested that there were three compartments into which $\mathrm{Cl}^{-}$penetrated: interstitial, glial, and neuronal. However, this is speculation and more recent work (as will be discussed) would not support such conclusions although the penetration of $\mathrm{Cl}^{-}$into cells of the CNS cannot be excluded. It can be calculated from available data $(46,110)$ from these workers that rats at 8 days of life had a ${ }^{36} \mathrm{Cl}^{-}$space of $56 \%$ whereas in the
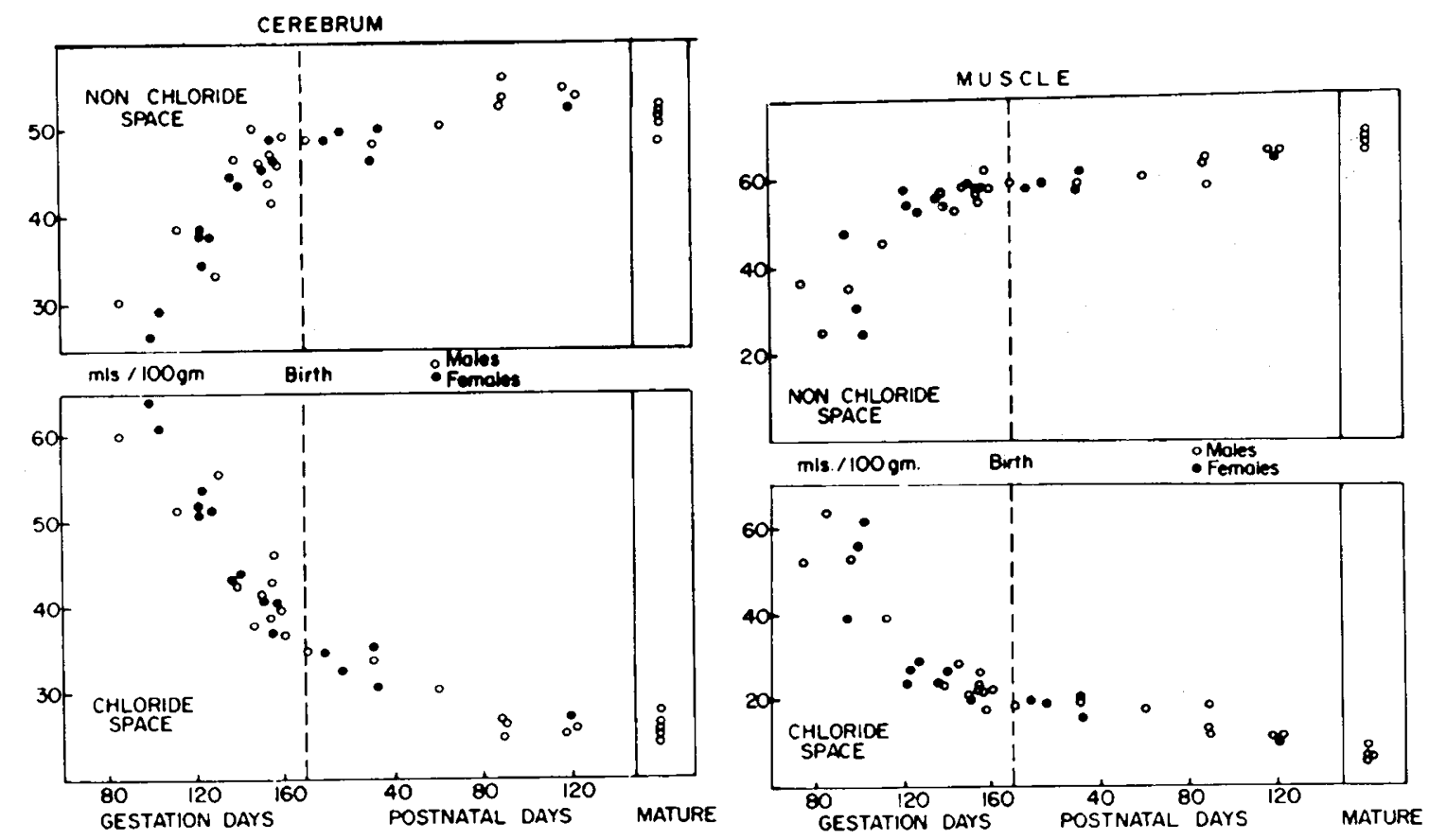

Fig. 2. The change in volume of the chloride and nonchloride spaces (expressed as $\mathrm{ml} / 100 \mathrm{~g}$ ) are shown for cerebrum and skeletal muscle of $M$. mulatta during ontogeny. Note the similarity in pattern of change during growth of both tissues, and the sharp decline in the volume of distribution during the fetal period. The chloride space at maturity is distinctly larger in the cerebrum $(26 \mathrm{ml} / 100 \mathrm{~g})$ in comparison to skeletal muscle $(7 \mathrm{ml} / 100$ g). 
mature rat the ${ }^{36} \mathrm{Cl}^{-}$space of cerebral cortex was $30 \%$ (59). These values are much higher than the data published for their earlier study (112).

The important work of Ahmed and Van Harreveld (1) dealing with the distribution of iodide in the rabbit brain gives some insight into the dynamic equilibrium maintained for halogens in the ECF. When ${ }^{131} \mathrm{I}^{-}$was infused into the vascular system of rabbits with ligation of the renal vessels the volume of distribution in the brain was $2 \%$. Only a trace of ${ }^{131} \mathrm{I}^{-}$was present in the CSF. Depression of the active ${ }^{131} \mathrm{I}^{-}$transport by perchlorate increased the iodide space to $8 \%$ and the ${ }^{131} \mathrm{I}^{-}$concentration of the CSF was one-quarter of that present in plasma. By increasing plasma concentration of iodide to $20 \mathrm{mEq} /$ liter the distribution of this ion increased to $10.6 \%$. When iodide was added to a ventricular perfusate a distribution of $7 \%$ was obtained.

When ${ }^{131} \mathrm{I}^{-}$was perfused simultaneously into both the plasma and the ventricles to obtain equal concentration, the iodide space was $10.2 \%$. When iodide transport was depressed by

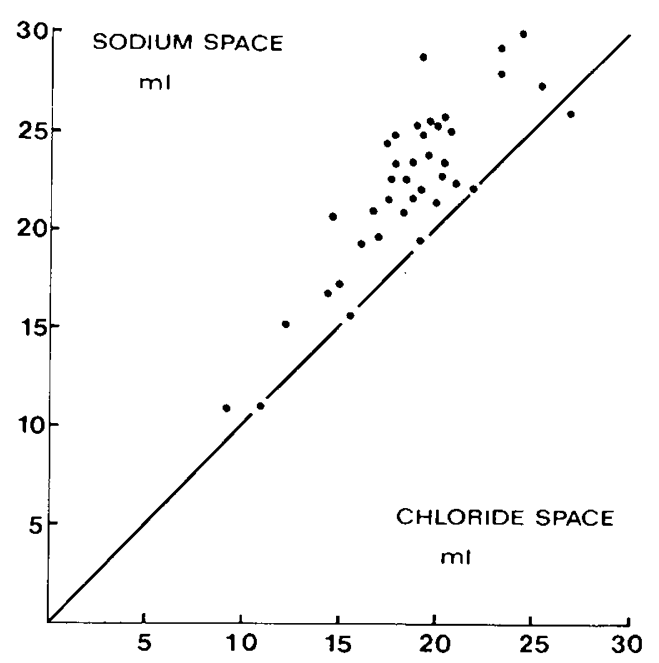

Fig. 3. In this figure the sodium space is plotted against the respective chloride space determined in individual prenatal and postnatal cerebrum of $M$. mulatta. The solid line indicates proportionality. Note that most of the estimates of the sodium space fall above the solid line, demonstrating a larger distribution of sodium space and, presumably, a cellular and extracellular location for sodium.

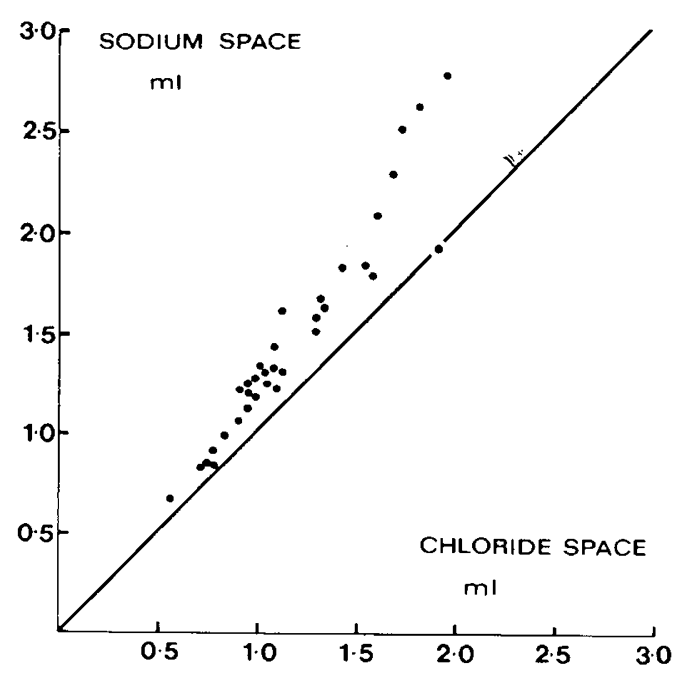

Fig. 4. The sodium space is plotted against the respective chloride space determined in prenatal and postnatal cerebellum. The solid line indicated proportionality. Note that all but one estimate of the sodium space falls above the solid line, again demonstrating a larger distribution of the sodium ion in comparison to chloride, and hence a cellular and extracellular location for sodium. perchlorate in the above experiment the space increased to $16.8 \%$. Intravenous administration of labeled and relatively large amounts of unlabeled iodide to a serum concentration of 20-40 $\mathrm{mM}$ and with simultaneous ventricular perfusion at the same concentration of iodide as in plasma yielded a maximum space of $22.5 \%$, which agrees with the endogeneous $\mathrm{Cl}^{-}$space and with the sulfate space (67).

These workers therefore were able to demonstrate that iodide is not only transported in both directions across the choroid plexus but that a significantly active transport occurs from the extracellular and/or intercellular fluid of the brain directly into blood capillaries or across the blood brain barrier. The multiple routes of entry and exit of $\mathrm{I}^{-}$into the ECV (Fig. 7) emphasizes the dynamic situation which appears to apply more to halogens than to other ions. This suggestion has been pursued by most

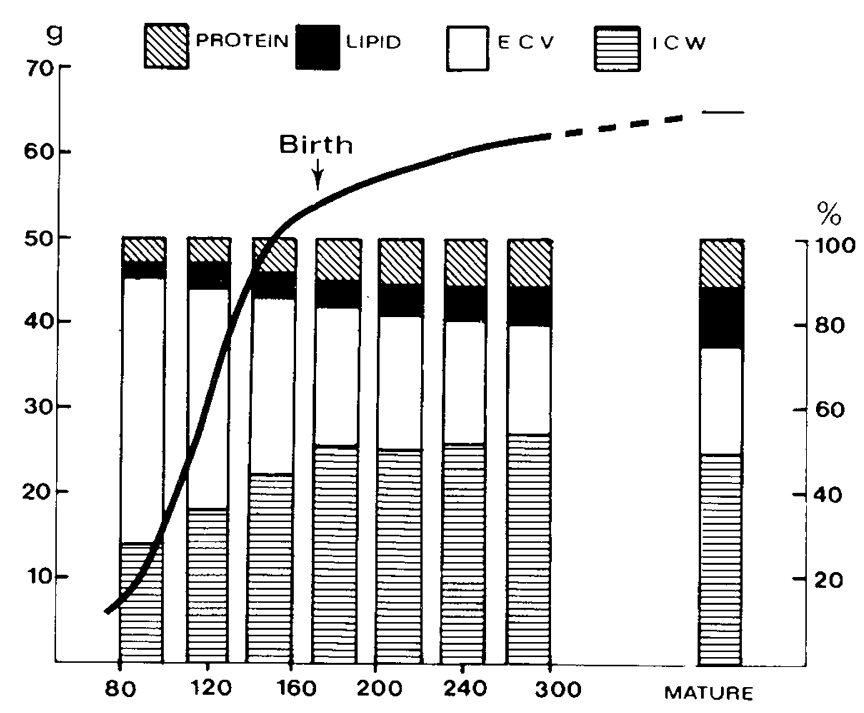

Fig. 5. The major components of cerebral composition are illustrated from midgestation into postnatal life for the rhesus monkey. Each bar represents the mean composition of the cerebrum for the age period indicated by the width of the bar. The solid line indicates the growth of mass of the cerebrum. Note the increments, particularly to the growth of the nonchloride space (an index of the cellular phase).

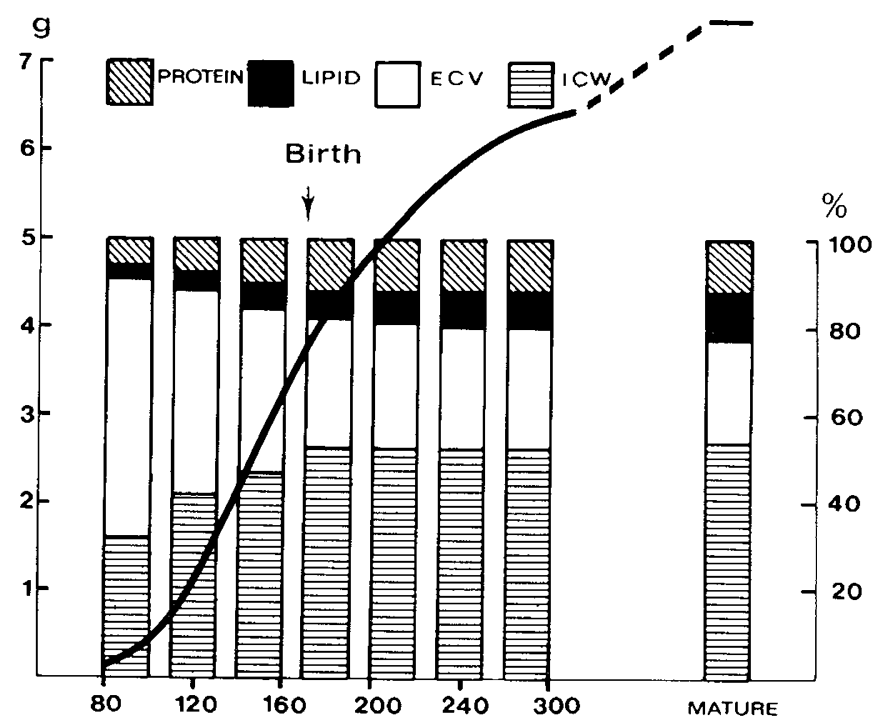

Fig. 6. Cerebellum composition from midgestation into postnatal life for the rhesus monkey. Each bar represents the mean percentage composition of the cerebellum for the age period indicated by the width of the bars. The growth in mass of the cerebellum is indicated by the solid line. Note the later and more rapid growth of the cerebellum compared to the cerebrum (Fig. 5). 


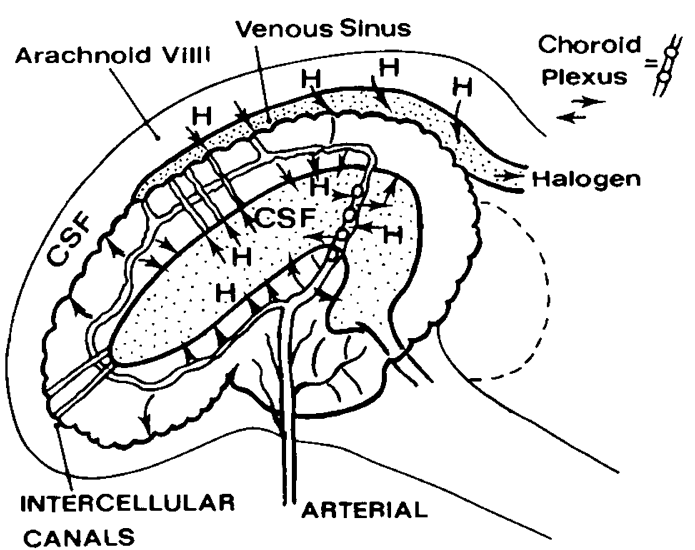

Fig. 7. This figure comprises the dynamic situation which appears to apply to the entry and exit of halogen $(\mathrm{H})$ ion in the cerebrum. This diagram indicates that halogen is not only transported both ways across the choroid plexus, but active transport also occurs from either the extracellular or intracellular fluids of the brain directly into blood capillaries or across the blood brain barrier. The full implications of halogen movement between the blood, CSF, and the intracellular fluids are dealt with in the text.

workers (93) but might have been predicted from the early work of Weir (113), which showed that the concentration of halogen determined the penetration into the $\mathrm{ECV}$ of the brain and into the CSF,

Bito et al. (9) also employed the simultaneous infusion of iodide into blood and ventricles of the rabbit with inhibition of iodide transport by perchlorate. A space of $19 \%$ was obtained (13\% with ventriculocisternal perfusion alone). Ahmed and Van Harreveld (1) interpreted Bito's study as showing that there was a need for high concentrations of $\mathrm{I}^{-}$to effectively define the ECV and to show the diffusion of iodide from the ECF and intercellular canals back into the blood. Ahmed and Van Harreveld (1) maintained equal and high (20-40 mM) concentrations of ${ }^{131} \mathrm{I}^{-}$in ventricular fluid and plasma in the presence of perchlorate. Probably such concentrations have to be maintained on either side of the barriers in order to prevent the escape of iodide into capillaries and venules and thus into the large systemic circulation. Bito et al. (9) showed that when the bromide and chloride spaces were compared using CSF as reference fluid the two spaces were identical in all pieces of brain and cord studied, thus confirming the earlier work of Wallace and Brodie $(111,112)$, which showed that the ECF of the brain appeared to be more in equilibrium with the CSF than with the vascular system.

Cutler et al. (30) showed by ventriculocisternal perfusion that transport out of the CSF differed for $\mathrm{SO}_{4}=$ and $\mathrm{I}^{-}$. High concentrations of ${ }^{35} \mathrm{SO}_{4}{ }=$ infused into plasma (higher than in CSF) did not alter the entrance of ${ }^{35} \mathrm{SO}_{4}=$ into the CSF $\left(c f . \mathrm{Br}^{-}\right)$. It was concluded that the ${ }^{35} \mathrm{SO}_{4}{ }{ }$ transport occurred against a concentration gradient. However, the addition of nonradioactive $\mathrm{SO}_{4}=$ to a ventriculocisternal perfusion reduced ${ }^{35} \mathrm{SO}_{4}{ }^{=}$transport by $66 \%\left(c f . \mathrm{I}^{-}\right)$, suggesting that structural analogs compete for the same transport mechanism. A similar competitive process occurs in the renal tubule (18).

High perfusate concentrations of $\mathrm{SO}_{4}=$ into the ventriculocisternal fluid did not accelerate the clearance of ${ }^{125} \mathrm{I}^{-}$and vice versa, but evidence was found that the transport out of the CSF into brain was different for these two anions. The choroid plexus was thought, by these workers, to be the major site for outward transport.

Thus, while we have noted the similarity in the distribution of halogens and $\mathrm{SO}_{4}=$, it is clear that iodide, for example, enters blood capillaries from intercellular canals and an exchange occurs across the choroid plexus in both directions. Thus the behavior of halogens and $\mathrm{SO}_{4}{ }{ }$ differ. The transport mechanisms differ even though they both encompass a similar space in the rabbit. We have used the overall term of halogen, but differences exist between the transport and distribution of $\mathrm{Cl}^{-}, \mathrm{Br}^{-}$, and $\mathrm{I}^{-}$. Probably the $\mathrm{Cl}^{-}$ion moves faster than the latter two and with a strong positive or active transport from blood across the choroid plexus to the CSF. In contrast, as pointed out by Pollay (84), $\mathrm{Br}^{-}$and $\mathrm{I}^{-}$are more strongly transported out of the CSF to blood and intercellular fluid. It is unfortunate that so little work has been done with isotopes of chloride in the assessment of these problems.

Bourke and Nelson (13) noted that after the injection of ${ }^{36} \mathrm{Cl}^{-}$ into blood, ${ }^{36} \mathrm{Cl}^{-}$entered the CSF, freely following saturation patterns rather than simple diffusional kinetics. They also demonstrated that $\mathrm{Cl}^{-}$not only enters the CSF across the choroid plexus but $\mathrm{Cl}^{-}$gains access via the cerebral vasculature.

An active transport system for $\mathrm{Cl}^{-}$in the kidney had long been suspected by the late William Wallace (95). In his opinion, the action of mercurial diuretics depended on inhibition of $\mathrm{Cl}^{-}$ transport. We now know that the distal segment of Henles loop reabsorbs $\mathrm{Cl}^{-}$primarily and actively (17).

\section{HOW DOES BRAIN VOLUME SUSTAIN CHANGES IN OSMOLALITY IN SYSTEMIC CIRCULATION?}

One argument for the use of potassium to define the cellular phase in the brain and chloride and sodium to establish the extracellular phase is the fact that hyponatremia leads to an increase in cell hydration with a whole range of physical symptoms and signs $(40,77)$. Indeed, acute and sustained hyponatremia is now recognized as a cause of brain damage. Clearly, the old rule still pertains; that osmolality has to be the same across both sides of the membrane and in the cell and the extracellular phase. The imposition of hypernatremia in the neonate has equally disastrous effects leading to reduction in brain cell volume and, on occasion, intracranial hemorrhage (47). However, there is reason to believe that changes in the volume of brain tissue with change in extracellular tonicity is less extensive than in somatic tissues.

Van Harreveld et al. (108) reviewed previous studies concerning over- and underhydration. They used the rabbit as a model and studied the effect of infusing either distilled water or $50 \%$ glucose into the systemic circulation. Either infusion produced no change in brain cell potassium, but the infusion of distilled water caused a $11-12 \%$ loss of $\mathrm{NaCl}$ from the extracellular phase of brain, whereas the injection of $50 \%$ glucose caused a $25 \%$ loss of sodium and a $21 \%$ loss of chloride.

The fact that in both of these situations $\mathrm{Na}^{+}$and $\mathrm{Cl}^{-}$move out of the extracellular space and intercellular canals into the plasma pool is of importance. We know from the work of Bering (8) that water (deuterium oxide) moves quickly into the brain and equilibrium with respect to $\mathrm{H}_{2} \mathrm{O}$ is rapidly established. In the situation where over hydration exists systemically, the ECV of the brain would tend to expand, but this expansion would be offset by the reduction of extracellular solute $\left(\mathrm{HCO}_{3}^{-}\right.$and $\mathrm{Na}^{+} \mathrm{Cl}^{-}$) and the passive transference of $\mathrm{H}_{2} \mathrm{O}$. By such means the increase of $\mathrm{H}_{2} \mathrm{O}$ in the cellular phase will be reduced to a minimum. The injection of added solute ( $50 \%$ glucose) into the systemic system also causes loss of ECF from the brain tissue. Here $\mathrm{Na}^{+}$and $\mathrm{Cl}^{-}$are also transferred back to the plasma pool while glucose may cross the barrier. In both instances a concentration gradient exists between the $\mathrm{Na}^{+}$and $\mathrm{Cl}^{-}$of the extracellular phase of the brain and the ECF of the soma. The transfer of $\mathrm{Na}^{+}$and $\mathrm{Cl}^{-}$acts to keep volume change in the brain to a minimum.

Holliday et al. (58) made important and detailed studies concerning $\mathrm{Cl}^{-}$space of the rat brain and the distribution of $\mathrm{Na}^{+} \mathrm{Cl}^{-}$and $\mathrm{K}^{+}$under conditions of acute or chronic hyponatremia or hypernatremia ( $1 \mathrm{hr}$ to 7 days). It was found that brain chloride content varied directly with the chloride concentration in the ECF. Thus, in studies where the $\mathrm{Cl}^{-}$content of the brain ranged from 8 to $28 \mathrm{mEq} / 100 \mathrm{~g}$ dried brain, the chloride concentration in an ultrafiltrate of serum ranged from $60-200$ $\mathrm{mEq} /$ liter. A linear regression was obtained for these two 
determinants where the intercept not significantly different from zero. Hence it was concluded that the two determinants moved in the same direction; as the chloride content of the brain decreased so did the concentration of chloride in an ultrafiltrate, thus allowing minimal change in the chloride space of the brain. The change in $\mathrm{Na}^{+}$concentration followed that of $\mathrm{Cl}^{-}$.

For control rats the sodium within the chloride space was $18.31 \mathrm{mEq} / 100 \mathrm{~g}$ dried brain whereas $4.18 \mathrm{mEq} \mathrm{Na}{ }^{+}$were assessed as intracellular. The regression of brain $\mathrm{Na}^{+}$content on extracellular $\mathrm{Na}^{+}$concentration (as an ultrafiltrate of serum) gave a linear regression similar to that obtained for $\mathrm{Cl}^{-}$under these widely varying conditions. However, the intercept was significantly different from zero $(4.55 \mathrm{mEq})$, and very similar to the calculated intracellular $\mathrm{Na}^{+}$content. It was concluded that neither extracellular $\mathrm{Na}^{+}$or $\mathrm{Cl}^{-}$acted to increase or decrease brain volume under these circumstances ( $c f$. the situation in other tissues where, for example, subtraction of cell water is easily achieved by the injection of $\mathrm{NaCl}$ into the $\mathrm{ECF}$ ). Clearly, $\mathrm{Na}^{+}$and $\mathrm{Cl}^{-}$are not restrained within the brain and active transport occurs between the circulation and the ECF of the brain to protect volume.

If the chloride space does change to some extent the question of alteration in intracellular volume arises. It was found that changes in brain volume were associated with alteration of the intracellular phase. In acute experiments the $\mathrm{K}^{+}$content did not change but in chronic experiments it was found that with hypernatremia, $\mathrm{K}^{+}$increased within the cellular phase. With hyponatremia, $\mathrm{K}^{+}$content decreased. Again, the regulating mechanisms move such that changes in intracellular volume were minimal but significant.

Holliday et al. (58) examined the content of $\mathrm{Na}^{+}+\mathrm{K}^{+}$in brain divided by brain water content $\left(\mathrm{Na}^{+}+\mathrm{K}^{+}\right) / \mathrm{V}$, giving an index of total electrolyte concentration or cation content/water content against extracellular $\mathrm{Na}^{+}$concentration (or osmolality) in an effort to det rrmine the relationship between cation concentration and osmolality. Again a linear regression was obtained. The value for $\left(\mathrm{Na}^{+}+\mathrm{K}^{+}\right) / \mathrm{V}$ was consistently greater than the $\left[\mathrm{Na}^{+}\right]_{\mathrm{e}}$ at any point. Thus there was a large positive intercept, indicating that a significant portion of brain cation is not osmotically active. By comparing this equation with the equation involving intracellular $\mathrm{K}^{+}+\mathrm{Na}^{+}$divided by the predicted intracellular volume, against $\left[\mathrm{Na}^{+}\right]_{\mathrm{e}}$, it became clear that for both regressions a value of about $80 \mathrm{mEq}$ represented an osmotically inactive solute. These studies shed new light on the regulation of brain electrolyte.

Penetration of ${ }^{36} \mathrm{Cl}^{-}$and ${ }^{22} \mathrm{Na}^{-}$from blood into brain under normal stable circumstances is relatively slow $(69,71)$ and the $\left[\mathrm{Na}^{+}\right]_{\mathrm{e}}$ and $\left[\mathrm{Cl}^{-}\right]_{\mathrm{e}}$ in CSF differ from those in plasma active transport mechanisms $(33,37)$. Clearly from Holliday's work a departure from equilibrium is associated with concomitant and rapid adjustments in the brain electrolyte over a few hours. Other studies confirm this thinking $(40,47,57,103,105,107$, 120) and involve situations where $\mathrm{Na}^{+}$and $\mathrm{Cl}^{-}$concentrations change significantly and systemically. One can also deduce from Holliday's work that the $\mathrm{Cl}^{-}$space must at least approximate the ECV of the brain.

Sotos et al. (100), by the use of rabbits, induced hyperosmolality with agents restricted mainly to the ECF $(\mathrm{NaCl}$, mannitol, etc.) or to the total body water (urea). They noted that the gradient produced between the ECF of the body and the brain is the important factor that initiates the characteristic symptoms leading to death. Thus the gradient across the blood brain barrier has great physiologic and pathologic importance.

\section{WHAT MORPHOLOGIC EVIDENCE EXISTS TO SUPPORT OR DISCOUNT THE CHLORIDE SPACE AS A MEASURE OF ECV OF BRAIN?}

During the last decade it was thought that chloride was of questionable value as a marker in brain tissue. The contention reached a high point when electron microscopists, using routine methods, were unable to account for an extracellular space of more than 3 or $5 \%$ in mature brain tissues taken several minutes after death (96). As these values agreed with the distribution of certain chemical markers (measuring the plasma or interstitial space), the subject appeared to be closed (106).

Pysh (89), using a glutaraldehyde technique, undertook the histologic study of brain development in the postnatal period in the rat with special attention to the inferior colliculus. Electron microscopy revealed "large extracellular lakes" in neonatal rat brain. These intercellular spaces or "lakes" were interconnected by canals of 100 to $150 \AA$ in diameter and during development the lakes progressively decreased in size but the canals persisted. After 14 days these lakes were difficult to detect. Active growth in the inferior colliculus occurs during the first 14 days such that the width of the neuropile increases 3-or 4-fold. The lakes were identified with ruthenium red and likewise the presence of intercellular glycoprotein or mucopolysaccharide was detected.

Sumi (102) also has described large extracellular lakes and clefts in the newborn rat which decrease to adult size at 14 days. Karlsson (62) and Del Cerro et al. (38) have demonstrated similar findings in rats. However, the above histologic studies were not done using the freeze substitution technique and are therefore of limited value (see below). However, it would appear that the existence of lakes and canals in these studies are valid.

Van Harreveld et al. (106) developed the freeze substitution method by rapidly freezing brain tissues $(30 \mathrm{sec})$ and by contact with polished silver maintained at about $-207^{\circ}$. The tissue was subjected to substitution fixation method using acetone containing $2 \%$ osmium tetroxide at $-85^{\circ}$ for 2 days. Preparation for electron microscopy was by embedding the tissue in Maraglas while sectioning and staining with either lead citrate or uranyl acetate and lead. These workers showed that if this approach was used, morphology was preserved in brain tissue, whereas a lapse of $8 \mathrm{~min}$ associated with asphyxiation caused the extracellular space to disappear or to be reduced to narrow clefts between opposing cell surfaces. Indeed, earlier work by Katzman (64) showed that morphologic measurement of the extracellular space without taking into account asphyxia resulted in an ECV of 3-5\%. Moreover, the use of formaldehyde or glutaraldehyde as fixatives reduces the apparent extracellular space even more (63).

The important feature of estimating the ECV morphologically by the Van Harreveld method is freezing of the entire tissue instantaneously and uniformly so that no isolated ice crystals form, thus preventing water and electrolyte deposits from entering the intracellular phase. It is known that almost immediately after asphyxia $\mathrm{Na}^{+}$and $\mathrm{Cl}^{-}$enter the intracellular phase by Donnan forces and water follows these ions rapidly (14). This technique is liable to underestimate slightly the extracellular space as a few small ice crystals may form deep inside the tissue. By this method Van Harreveld et al . (106) found appreciable $\mathrm{ECV}$ in brain tissue and, for the mature cerebellum (vermis), defined a volume of $23.6 \%$.

Extracellular space can be estimated also from the measurement of electric impedence of the tissue. The electric current is carried by extracellular electrolyte since the high resistance of the limiting cell membrane prevents movement of intracellular ions. From this approach it was estimated by Van Harreveld and Schade (108) that the brain cortex had an ECV of $25 \%$ or greater. Such values agree with rapid freeze-substitution technique, and further studies using impedence substantiated once again the presence of a considerable extracellular phase (108),

However, other workers continued to point out that these data were in conflict with certain chemical tracers of the ECF injected into the circulation. Such markers included polysaccharides or disaccharides which, as we have discussed at length, monitor in all probability only a portion of the ECV. Others have considered that neuroglial cells are part of the extracellular phase containing large amounts of $\mathrm{NaCl}(110)$. These would give $\mathrm{Na}^{+}$and $\mathrm{Cl}^{-}$easy access and would explain the larger 
chloride space of brain. Minutes after death, ECF enters the cellular phase and electric impedence decreases while Donnan forces transfer $\mathrm{NaCl}$ into cells (see Refs. 96 and 106 for review). This has to be taken into account when extracellular markers are used. The great need is for morphologic studies combined with the use of tracers to measure ECV in the brain.

Bondareff and Pysh (11) inspected the extracellular space of rat cerebral cortex during postnatal development using the Van Harreveld rapid freeze fixation technique with gradual substitution of frozen tissue water with acetone. They confirmed the findings of Van Harreveld. Extracellular space was determined stereologically and presented as a percentage in four age groups $(10,14,21$ days, and young adults), as values of $40.5,31.8$, 26.3, and 21.7. These workers (11) noted large extracellular spaces distributed as irregularly shaped lakes of variable dimension containing a large proportion of extracellular water. Such canals facilitate diffusion of extracellular ions and metabolites. Similar morphologic findings were made by Van Harreveld et al . (106). Diamond and Tormey (39) demonstrated the importance of such canals for fluid transport across epithelia. Similarly, Nicholls and Kuffler (79) noted clefts between glial cells and neurones in amphibian nervous tissue serving as canals for the rapid diffusion of ions. Moreover, this extracellular space of brain relates to the spinal fluid and blood brain barrier as discussed (56).

It is important to emphasize that the data of Vernadakis and Woodbury (109) for ECV in rat cortex by measurement of the endogenous $\mathrm{Cl}^{-}$space are identical with the morphologic studies of Bondareff and Pysh (11). If one plots both sets of data against age the points fall on a common line (59).

Thus, the existing information from morphologic studies supports the concept that the $\mathrm{Cl}^{-}$space of brain is a close measure of true ECV.

\section{CONCLUSION}

The CSF and the ECV of the brain are comparable with the lymphatic system of the soma. This fluid conveys nutrients, proteins, and hormones (probably more than have been appreciated) while disposing of the waste products of metabolism and maintaining a "milieu" ideal for nervous conduction.

The CSF comes from the choroid plexus but also is secreted from the ventricular walls and subarachnoid pial surfaces. The CSF oscillates continuously because of systemic blood pressure and is drained away through arachnoid villi of the sagittal sinus and via the spinal subarachnoid space.

The ECV of the brain together with the CSF comprise a twocompartment system where exchange of ions occurs in both directions between the blood and CSF mainly at the choroid plexus by active transport mechanisms (the blood-CSF barrier). At the same time, the arterioles in the brain and the surrounding epithelia, astrocytes, and membrane constitute a second barrier (the blood-brain barrier) through which ions can penetrate. All barrier sites are characterized by cells connected by "tight junctions" that restrict intercellular diffusion. The cells themselves regulate ion transport.

Within the brain, lakes exist during development but with maturation, canals remain at a diameter of 100-150 $\AA$. Transport of ions, especially halogen, can occur from the canals into the blood. The interstitial fluid surrounding the vessels and fluid within the intercellular canals and the CSF all form part of the ECV of the brain. To establish the volume of distribution of an ion such as halogen, one has to perfuse the circulation to the brain together with the ventriculocisternal area at a similar concentration and at a level that will saturate the transport mechanisms so as to prevent the escape of ions back into the systemic circulation.

It would appear that $\mathrm{SO}_{4}=$ and halogens give volumes of distribution that are similar whereas polysaccharides yield volumes that are significantly smaller in the brains of various mammals.

Solutes can differ in their ability to penetrate the ECV.
Polysaccharides, for example, are not transported out of the $\mathrm{CSF}$. Even small ions such as $\mathrm{SO}_{4}{ }^{=}$and halogen differ in their transport mechanisms.

It would appear that chloride ion movement is more rapid and more strongly transported across from blood to CSF compared with $\mathrm{Br}^{-}$or $\mathrm{I}^{-}$. Indeed, chloride may have the easiest passage across both barriers and may penetrate the intercellular canals with facility.

Only recently have histologic techniques reached a stage where morphologic structure of the brain is preserved. The application of these techniques reveal values for ECV impedence studies.

The ECV of the brain reacts to changes in tonicity in the systemic circulation by changing the transport of $\mathrm{Na}^{+}$and $\mathrm{Cl}^{-}$in a direction to counter changes in ECV and hence to protect and maintain cellular volume.

\section{REFERENCES AND NOTES}

1. Ahmed, N., and Van Harreveld, A.: The iodide space in rabbit brain. J. Physiol. (London), 204: 31 (1969).

2. Ames, III, A., and Nesbett, F. B.: Intracellular and extracellular compartments of mammalian central nervous tissue. J. Physiol. (London), 184: 215 (1966).

3. Anderson, J. A.: Lead poisoning. In: W. E. Nelson, V. C. Vaughan, and R. J. McKay: Textbook of Pediatrics, p. 1490 (W. B. Saunders, Philadelphia, 1969).

4. Aprison, M. H., Lukenbill, A., and Segar, W. E.: Sodium, potassium, chloride and water content of six discrete parts of the mammalian brain. J. Neurochem., $5150(1960)$.

5. Barlow, C. F., Domek, N. S., Goldberg, M. A., and Roth, L. J.: Extracellular brain space measured by $\mathrm{S}^{35}$ sulfate. Arch. Neurol., 5: 102 (1961).

6. Barratt, T. M., and Walser, M.: Extracellular fluid in individual tissues and in whole animals: The distribution of radiosulfate and radiobromide. J. Clin. Invest., 48: 56 (1969).

7. Bass, N. H., and Lundborg, P.: Cerebral edema: The effect of dexamethasone during brain maturation in the rat. Arch. Neurol., 29: 151 (1973),

8. Bering, E. A.: The cerebrospinal fluid and the extracellular fluid of the brain. Fed. Proc., 33: 2061 (1973).

9. Bito, L. A., Bradbury, M. W. B., and Davson, H.: Factors affecting the distribution of iodide and bromide in the central nervous system. J. Physiol. (London), 185: 323 (1966).

10. Bondareff, W., Myers, R. E., and Brann, A. W.: Brain extracellular space in monkey fetuses subjected to prolonged partial asphyxia. Exp. Neurol., 28: 167 (1970).

11. Bondareff, W., and Pysh, J. J.: Distribution of the extracellular space during postnatal maturation of rat cerebral cortex. Anat. Rec., 160: 773 (1968).

12. Bourke, R. S., Greenberg, E. S., and Tower, D. B.: Variations of cerebral cortex fluid spaces in vivo as a function of species brain size. Amer. J. Physiol., 208: 682 (1965).

13. Bourke, R. S., and Nelson, K. M.: Studies on the site of mediated transport of chloride from blood into cerebrospinal fluid: Effects of acetaxolamide. J. Neurochem., 19: 1225 (1972).

14. Brann, A. W., and Myers, R. E.: Central nervous system findings in the newborn monkey following severe in utero partial asphyxia. Neurology, 25: 327 (1975).

15. Brodie, B. B., Brand, E., and Leshin, S.: The use of bromide as a measure of extracellular fluid. J. Biol. Chem., 130: 555 (1939).

16. Brown, D. A., Stumpf, W. E., and Roth, L. J.: Location of radioactively labelled extracellular fluid indicators in nervous tissue by autoradiography. J. Clin. Sci., 4: 265 (1969)

17. Burg, M. B.: (Editorial) Renal chloride transport and diuretics. Circulation, 53: 587 (1976).

18. Burgland, F., Helander, C. G., and Hare, R. G.: Inorganic sulfate and thiosulfate: Transport and competition in renal tubules of the dog. Amer. J. Physiol., 198: 586 (1960).

19. Cheek, D. B.: Further observations on electrolyte change in tuberculous meningitis: The ratio of the concentrations of bromide in serum and cerebrospinal fluid. Pediatrics, $18: 218$ (1956).

20. Cheek, D. B.: Extracellular volume: Its structure and measurement and the influence of age and disease. J. Pediat., 58: 103 (1961).

21. Cheek, D. B. (ed.): Fetal and Postnatal Cellular Growth: Hormones and Nutrition (John Wiley \& Sons, New York, 1975).

22. Cheek, D. B., and Graystone, J. E.: Metabolic change in purulent and tuberculous meningitis. Amer. J. Dis Child., 105: 542 (1963).

23. Cheek, D. B., and West, C. D.: An appraisal of methods of tissue chloride analysis: The total carcass chloride, exchangeable chloride, potassium and water of the rat. J. Clin. Invest., 34: 1744 (1955).

24. Cheek, D. B., West, C. D., and Golden, C. C.: The distribution of sodium and chloride and the extracellular fluid volume in the rat. J. Clin. Invest., 36: 340 (1957)

25. Cotlove, E.: Mechanisms and extent of distribution of inulin and sucrose in chloride space of tissues. Amer. J. Physiol., 176: 396 (1954).

26. Cotlove, E.: Determination of the true chloride content of biological fluids 
and tissues. II. Analysis by simple, nonisotopic methods. Anal. Chem., 35: 101 (1963).

27. Crook, A., Duncan, H., Gutteridge, B., and Pallis, C: Use of ${ }^{82} \mathrm{Br}$ in differential diagnosis of lymphocytic meningitis. Brit. Med. J., 1: 704 (1960).

28. Csaky, T. Z.: Choroid plexus. In: A. Lajtha: Handbook of Neurochemistry, Vol. 2., Structural Neurochemistry, p. 49 (Plenum Press, New York, 1969).

29. Cutler, R. W. P., Barlow, C. F., Lorenzo, A. V.: The effect of braincerebrospinal fluid diffusion gradients on the determination of extracellular space in cat brain. J. Neuropathol. Exp. Neurol., 26: 167 (1967).

30. Cutler, R. W. P., Lorenzo, A. V., and Barlow, C. F.: Sulfate and iodide concentration in brain: The influence of cerebrospinal fluid. Arch. Neurol., 18: 316 (1968)

31. Cutler, R. W. P., Robinson, R. J., and Lorenzo, A.V.: Cerebrospinal fluid transport of sulfate in the cat. Amer. J. Physiol., 214: 448 (1968).

32. Cuypers, J., Matakas, F., and Potolicchio, S. T.: Effect of central venous pressure on brain tissue pressure and brain volume. J. Neurosurg., 45: 89 (1976)

33. Davson, H.: The cerebrospinal fluid. In: A. Lajtha: Handbook of Neurochemistry, Vol. 2., Structural Neurochemistry (Plenum Press, New York, 1969).

34. Davson, H., Domer, F. R., and Hollingsworth, J. R.: Mechanism of drainage of the CSF. Brain, 96: 329 (1973)

35. Davson, H., Kleeman, C. R., and Levin, E.: Blood-brain barrier and extracellular space. J. Physiol. (London), 159: 67 (1961)

36. Davson, H., Kleeman, C. R., and Levin, E.: Quantitative studies of the passage of different substances out of the cerebrospinal fluid. J. Physiol. (London), 161: 126 (1962).

37. Davson, H., and Spaziani, E.: The blood-brain barrier and the extracellular space of brain. J. Physiol., 149: 135 (1959)

38. Del Cerro, M. P., Snider, R. S., and Oster, M. L.: Evolution of the extracellular space in immature nervous tissue. Experientia, 24: 929 (1968).

39. Diamond, J. M., and Tormey, J. M.: Role of long extracellular channels in fluid transport across epithelia. Nature, 210, 817 (1966).

40. Dodge, P. R., Crawford, J. D., and Probst, J. H.: Studies in experimental water intoxication. Arch. Neurol., 3: 513 (1960).

41. Drewes, L. R., and Gilboe, D. D.: Nutrient transport systems in dog brain. Fed. Proc., 36: 166 (1977).

42. Duck, S. C., Weldon, V. V., Pagliara, A. S., and Haymond, M. W.: Cerebral edema complicating therapy for diabetic ketoacidosis. Diabetes, 25: 111 (1976).

43. Edelman, I. S., and Leibman, J.: Anatomy of body water and electrolytes. Amer. J. Med., 27: 256 (1959).

44. Endo, M.: Entry of a dye into the sarcotubular system of muscle. Nature, 202: 1115 (1964)

45. Fenstermacher, J. D., Patlak, C. S., Levin, V. A., and Rall, D. P.: The permeability of brain cells and capillaries to various water-soluble molecules as determined by ventriculocistemal perfusion. Fed. Proc. 28: 578 (1969).

46. Ferguson, R. K., and Woodbury, D. M.: Penetration of ${ }^{14} \mathrm{C}$-sucrose into brain, cerebrospinal fluid, and skeletal muscle of developing rats. Exp. Brain Res., 7: 181 (1969)

47. Finberg, L., Luttrell, C., and Redd, H.: Pathogenesis of lesions in the nervous system in hypernatremic states. II. Experimental studies of gross anatomic changes and alterations of chemical composition of the tissues. Pediatrics, 23: 46 (1959).

48. Finkensteaedt, J. T., O'Meara, M. P., and Merrill, J. P.: Observations on the volume of distribution of inulin in anuric subjects. J. Clin. Invest., 32: 209 (1953).

49. Flexner, L. B., and Flexner, J. B.: Biochemical and physiological differentiation during morphogenesis. IX. The extracellular and intracellular phases of the liver and cerebral cortex of the fetal guinea pig as estimated from distribution of chloride and radiosodium. J. Cell. Comp. Physiol., 34: 115 (1949).

50. Gamble, J. L., Jr., and Robertson, J. S.: Volume of distribution of radioactive chloride in dogs: Comparison of sodium, bromide and inulin spaces. Amer. J. Physiol., 171: 659 (1952).

51. Gamble, Jr., J. L., Robertson, J. S., Hannigan, C. A,, Foster, C. G., and Farr, L. E.: Chloride, bromide, sodium and sucrose spaces in man. J. Clin. Invest., 32: 483 (1953)

52. Girardier, L., Reuben, J. P., Brandt, P. W., and Grundfest, H.: Evidence for excitation-contraction coupling. J. Gen. Physiol., 47: 189 (1963).

53. Goldmann, E. E.: Vitalfarbung am Zentralnervensystem. Abhandl. Preuss. Akak. Wiss. Phys. Math. K., 1:1 (1913)

54. Hastings, A. B., and Eichelberger, L.: Exchange of salt and water between muscle and blood: Effect of increase in total body water produced by intravenous injection of isotonic salt solutions. J. Biol. Chem., 73 (1937).

55. Hellerstein, S., Kaiser, C., Darrow, D., and Darrow, D. C.: The distribution of bromide and chloride in the body. J. Clin. Invest., 39: 282 (1959).

56. Himwich, W. A., Petersen, J. C., and Allen, M. L.: Hematoencephalic exchange as a function of age. Neurology, 7: 705 (1957).

57. Hogan, G. R., Dodge, P. R., Gill, S. R., Master, S., and Sotos, J. F.: Pathogenesis of seizures occurring during restoration of plasma tonicity to normal in animals previously chronically hypernatremic. Pediatrics, 43: 54 (1969).

58. Holliday, M. A., Kalayci, M. N., and Harrah, J.: Factors that limit brain volume changes in response to acute and sustained hyper- and hyponatremia. J. Clin. Invest., 47: 1916 (1968).
59. Holt, A. B., Hill, D. E., and Cheek, D. B.: Morphological and biochemica correlates in brain. In: D. B. Cheek: Fetal and Postnatal Cellular Growth: Hormones and Nutrition, pp. 45-54 (John Wiley \& Sons, New York 1975).

60. Horstmann, E, and Meves, M.: Die Feinstruktur des molekularen Rindengraues and ihre physiologische Bedeutung. Z. Zellforsch. Mikroskop. Anat., 49: 569 (1959).

61. Huxley, H. E.: Evidence for continuity between the central elements of the triads and extracellular space in frog sartorius muscle. Nature, 202, 1067 (1964).

62. Karlsson, U.: Observations on the postnatal development of neuronal structures in the lateral geniculate nucleus of the rat by electron microscopy. J. Ultrastruct. Res., 17: 158 (1967).

63. Karlsson, U., and Schultz, R.: Plasma membrane apposition in the central nervous system after aldehyde perfusion. Nature, 201: 1230 (1964).

64. Katzman, R.: Electrolyte distribution in mammalian central nervous system Neurology, 11: 27 (1961).

65. Katzman, R., Lehrer, G. M., and Wilson, C. E.: Possible intraneuronal location of an "extracellular" tracer ${ }^{14} \mathrm{C}$-sucrose. J. Neuropathol. Exp. Neurol., 29: 167 (1967).

66. Katzman, R., Schimmel, H., and Wilson, C. E.: Diffusion of inulin as a measure of extracellular fluid space in brain. Proc. Rudolf Virchow Med. Soc. N. Y. (Suppl.), 26: 254 (1968).

67. Levin, E., Arieff, A., and Kleeman, C. R.: Evidence of different compartments in the brain for extracellular markers. Amer. J. Physiol., 221: 1319 (1971).

68. Levin, V. A., Fenstermacher, J. D., and Patlak, C. S.: Sucrose and inulin space measurements of cerebral cortex in four mammalian species. Amer. J. Physiol., 219: 1528 (1970).

69. Manery, J. F., and Bale, W. F.: The penetration of radioactive sodium and phosphorus into the extra- and intra-cellular phases of tissues. Amer. J. Physiol., 132: 215 (1941).

70. Manery, J. F., Danielson, I. S., and Hastings, A. B.: Connective tissue electrolytes. J. Biol. Chem., 124: 359 (1938).

71. Manery, J. F., and Haege, L. F.: The extent to which radioactive chloride penetrates tissues, and its significance. Amer. J. Physiol., 134: 83 (1941).

72. Manery, J. F., and Hastings, A. B.: The distribution of electrolytes in mammalian tissues. J. Biol. Chem., 127: 657 (1939).

73. Medzihrudsky, F., Sellenger, O. Z., Nandhasri, P. S., and Santiago, J. C.: Adenosine triphosphatase activity in glial cells and in neuronal perikarya of edematous rat brain. Brain Res., 67: 133 (1974).

74. Milhorat, T. H.: Choroid plexus and cerebrospinal fluid production. Science, 166: 1514 (1969).

75. Milhorat, T. H.: Hydrocephalus and the Cerebrospinal Fluid (Williams \& Wilkins, Baltimore, 1972).

76. Milhorat, T. H., Hammock, M. K., and Fenstermacher, J, D., Rall, D. P., and Levin, Y. A.: Cerebrospinal fluid production by the choroid plexus and brain. Science, 173: 330 (1971).

77. Millichap, J. G., Balter, M., and Hernandez. P.: Development of susceptibility to seizures in young animals. III. Brain water, electrolyte and acidbase metabolism. Proc. Soc. Exp. Biol. Med., 99: 6 (1958).

78. Morrison, A. B.: The distribution of intravenously-injected inulin in the fluids of the nervous system of the dog and rat. J. Clin. Invest., 38: 1769 (1959).

79. Nichols, J. G., and Kuffler, S. W.: Extracellular space as a pathway for exchange between blood and neurons in the central nervous system of the leech: Ionic composition of glial cells and neurons. J. Neurophysiol., 27: 645 (1964).

80. Nicholls, J. G., and Wolfe, D. E.: Distribution of ${ }^{14} \mathrm{C}$-labelled sucrose, inulin and dextran in extracellular spaces and in cells of the leech central nervous system. J. Neurophysiol., 30: 1574 (1967).

81. Nichols, G. Jr., Nichols, N., Weill, W. B. and Wallace, W. M.: The direct measurement of the extracellular phase of tissues. J. Clin. Invest., 31: 652 (1952).

82. Oldendorf, W. H., and Davson, H.: Brain extracellular space and the sink action of cerebrospinal fluid. Arch. Neurol., 17: 196 (1967).

83. Pappius, H. M., and Elliott, K. A. C.: Water distribution in incubated slices of brain and other tissues. Can. J. Biochem. Physiol., 34: 1007 (1956).

84. Pollaym, M.: Transport mechanisms in the choroid plexus. Fed. Proc., 33: 2064 (1974).

85. Pollay, M.: Formation of cerebrospinal fluid. In: N. Lundberg, U. Ponten, and M. Brock: Intracranial Pressure, Vol. II, pp. 20-23 (Springer-Verlag, New York, (1975)

86. Pollay, M., and Davson, H.: The passage of certain substances of the cerebrospinal fluid. Brain, 86: 137 (1963)

87. Pollay, M., and Kaplan, R. J.: The effect of the CSF sink on thiocyanate concentration gradient in brain. Amer. J. Physiol., 219: 802 (1970),

88. Pollay, M., and Kaplan, R. J.: Diffusion of non-electrolytes in brain tissue. Brit. Res., 17: 407 (1970).

89. Pysh, J. J.: The development of the extracellular space in neonatal rat inferior colliculus: An electron microscopic study. Amer. J. Anat., 124: 411 (1969).

90. Rall, D. P., Oppelt, W. W., and Patlak, C. S.: Extracellular space of brain as determined by diffusion of inulin from the ventricular system. Life Sci., 1(2): 43 (1962).

91. Reed, D. J., and Woodbury, D. M.: Kinetics of $\mathrm{C}^{14}$-sucrose distribution in cerebral cortex, cerebrospinal fluid, and plasma of rats. Fed. Proc., 19: 80 (1960).

92. Rapoport, S. I.: Blood Brain Barrier in Physiology and Medicine, p. 53 (Raven Press, New York, 1976) 
93. Reed, D. J., and Woodbury, D. M.: Kinetics of movement of iodide; sucrose, inulin and radio-iodinated serum albumin in central nervous system and cerebrospinal fluid of rats. J. Physiol. (Lond.), 169: 816 (1963).

94. Reed, D. J., Woodbury, D. M., and Holtzer, L.: Brain edema, electrolytes and extracellular space. Arch. Neurol., 10: 604 (1964).

95. Schwartz, W. B., and Wallace, W. M.: Electrolyte equilibrium during mercurial diuresis. J. Clin. Invest., 30: 1089 (1951).

96. Selzer, M. E., Myers, R. E., and Holstein, S. B.: Maturational changes in brain water and electrolytes in rhesus monkey with some implications for electrogenesis. Brain Res., 45: 193 (1972).

97. Shank, B. B., and Smith, N. E.: Regulation of cellular growth by sodium pump activity. J. Cell. Physiol., 87: 377 (1975).

98. Shaywitz, B. A. and Escriva, A.: Brain inulin space in developing kittens using ventriculocisternal perfusion. Neurology, 22: 238 (1972).

99. Slautterback, D. B.: The ultrastructure of cardiac and skeletal muscle. In: E. J. Briskey, R. G. Cassen, and J. C. Trautman: The Physiology and Biochemistry of Muscle as a Food, p. 39 (University of Wisconsin Press, Madison, 1966).

100. Sotos, J. F., Dodge, P. R., Meara, P., and Talbot, N. B.: Studies in experimental hypertonicity. I. Pathogenesis of the clinical syndrome, biochemical abnormalities and cause of death. Pediatrics, 26: 925 (1960).

101. Streicher, E.: Thiocyanate space of rat brain. Amer. J. Physiol., 201: 334 (1961).

102. Sumi, S. M.: The extracellular space in the developing rat brain: Its variation with changes in osmolarity of the fixative, method of fixation and maturation. J. Ultrastructural Res., 29: 398 (1969).

103. Swinyard, E. A.: Effect of extracellular electrolyte depletion on brain electrolyte pattern and electroshock seizure threshold. Amer. J. Physiol., 156: 163 (1949)

104. Tower, D. B., and Bourke, R. S.: Fluid compartmentation and electrolytes of cat cerebral cortex in vitro. III. Ontogenetic and comparative aspects. J. Neurochem., 23: 1119 (1966).

105. Van Harreveld, A., Collewijn, H., and Malhotra, S. K.: Water, electrolytes and extracellular space in hydrated and dehydrated central nervous tissue. Amer. J. Physiol. 210: 251 (1966).

106. Van Harreveld, A., Crowell, J. and Malhotra, S. K.: A study of extracellular space in central nervous tissue by freeze-substitution. J. Cell Biol., 25: 117 (1965).

107. Van Harreveld, A., and Dubrovsky, B. L.: Water and electrolytes in hydrated grey and white matter. Brain Res., 4: 81 (1967).

0031-3998/1205-0635\$02.00/0

Copyright (C) 1978 International Pediatric Research Foundation, Inc.
108. Van Harreveld, A., and Schade, J. P.: On distribution and movement of water and electrolytes in the cerebral cortex. In: D. B. Tower and J. P. Schade: Structure and Function of the Cerebral Cortex, Proceedings of the Second International Meeting of Neurobiology, p. 239 (Elsevier, Amsterdam, 1960).

109. Vernadakis, A., and Woodbury, D. M.: Electrolyte and amino acid changes in rat brain during maturation. Amer. J. Physiol., 203: 748 (1962).

110. Vernadakis, A., and Woodbury, D. M.: Cellular and extracellular spaces in developing rat brain. Arch. Neurol. (Chicago), 12: 284 (1965).

111. Wallace, G. B., and Brodie, B. B.: The distribution of administered bromide in comparison with chloride and its relation to body fluids. J. Pharmacol. Exp. Ther., 65: 214 (1939).

112. Wallace, G. B., and Brodie, B B.: The distribution of iodide, thiocyanate, bromide and chloride in the central nervous system and spinal fluid. J. Pharmacol. Exp. Ther., 65: 220 (1939).

113. Weir, E. G.: The influence of the serum bromide concentration upon the distribution of bromide ion between serum and spinal fluid. Amer. J. Physiol., 137: 109 (1942).

114. Weir, E. G., and Hastings, A. B.: The distribution of bromide and chloride in tissues and body fluids. J. Biol. Chem., 129: 547 (1939).

115. Welch, K., and Friedman, V.: The cerebrospinal fluid valves. Brain, 83: 454 (1960).

116. White, H. L., and Rolf, D.: Inulin space as a function of equilibration time. Amer. J. Physiol., 185: 152 (1956).

117. Woodbury, D. M.: Distribution kinetics of injected ions in rat cerebral cortex. In: W. W. Windle: Biology of Neuroglia, p. 120 (Charles C Thomas, Springfield, Ill., 1958)

118. Woodbury, D. M. Timiras, P. S. Koch, A and Ballard, A. Distribution of radiochloride, radiosulfate and inulin in brain of rats, Fed. Proc., 15: 501 (1956).

119. Woodward, D. O., Reed, D. J., and Woodbury, D. M.: Extracellular space of rat cerebral cortex. Amer. J. Physiol., 212: 367 (1967)

120. Yannett, H.: Changes in the brain resulting from depletion of extracellular electrolytes. Amer. J. Physiol., 128: 683 (1940).

121. Zadunaisky, J. A., and Curran, P. F.: Sodium fluxes in isolated frog brain. Amer. J. Physiol., 205: 949 (1963).

122. Requests for reprints should be addressed to: Dr. Donald B. Cheek, Royal Children's Hospital, Room S 1009, Flemington Road, Parkville, 3052 Victoria (Australia)

123. Received for publication January 14, 1977

124. Accepted for publication July 27, 1977 